УДК 342.951

https://doi.org/10.34142/23121661.2019.30.15

orcid.org/0000-0001-5400-8268

(C) Сердюк С.C., 2019

\author{
С.С. СЕРДЮК
}

\title{
АДМІНІСТРАТИВНО-ПРАВОВЕ РЕГУЛЮВАННЯ ЗАБЕЗПЕЧЕННЯ ПОЖЕЖНОЇ БЕЗПЕКИ В УКРАЇНІ В УМОВАХ ЄВРОІНТЕГРАЦІї
}

\section{S. SERDIUK}

\section{ADMINISTRATIVE AND LEGAL REGULATION OF SUPPLY FIRE SAFETY IN UKRAINE IN THE CONDITIONS OF EUROPEAN INTEGRATION}

\begin{abstract}
Анотація. У статті на основі аналізу адміністративного законодавства України охарактеризовано процес становлення та розвитку сучасної системи органів цивільного захисту, в тому числі й органів пожежної безпеки. Проведений аналіз організації та діяльності аналогічних органів країн Європейського Союзу з попередження надзвичайних ситуацій та ліквідації їх негативних наслідків. Пропонується врахувати позитивний досвід їх структурної побудови та адміністративно-правового регулювання діяльності в законодавстві України.
\end{abstract}

Ключові слова: адміністративно-правове регулювання, пожежна безпека, державна служба з надзвичайних ситуацій, цивільний захист, євроінтеграція.

Аннотация. В статье на основе анализа административного законодательства Украины охарактеризован процесс становления и развития системы органов гражданской защиты, в том числе и органов пожарной безопасности. Проведен анализ организации и деятельности аналогичных органов стран Европейского Союза по предупреждению чрезвычайных ситуаций и ликвидации их негативных последствий. Предлагается учесть положительный опыт их структурного построения и административно-правового регулирования деятельности в законодательстве Украины.

Ключевые слова: административно-правовое регулирование, пожарная безопасность, государственная служба по чрезвычайным ситуациям, гражданская защита, евроинтеграция.

Abstract. The article describes the process of formation and development of the modern system of civil protection bodies, including fire safety authorities, on the basis of the analysis of the administrative legislation of Ukraine. An analysis of the organization and activities of similar bodies of the European Union countries for the prevention of emergencies and the elimination of their negative consequences has been carried out. It is suggested to take into account the positive 
experience of their structural construction and administrative and legal regulation of activity in the legislation of Ukraine.

Keywords: administrative-legal regulation, fire safety, state service on emergencies, civil protection, european integration.

Сучасний стан соціально-економічного розвитку України на одне 3 перших місць ставить завдання захисту населення від негативного впливу пожеж, аварій, катастроф, стихійних лих та інших аномальних явищ техногенного і природного характеру, що є однією з найважливіших функцій держави. Протягом останніх десятиліть в Україні створена єдина державна система для вирішення найактуальнішого питання сьогодення - забезпечення техногенної і природної безпеки на території нашої країни.

У той же час ця система вимагає певної перебудови, що зумовлено потребами часу, тими змінами, які відбулися в економічній, політичній i соціальній сферах життя українського суспільства, а також закріплення в Конституції України [1] незворотності європейського курсу нашої держави, що зумовлює необхідність імплементації законодавства Свропейського Союзу в законодавство України. I це спонукало науковців на проведення подальших досліджень сучасних проблем адміністративно-правового забезпечення та практичної діяльності органів з надзвичайних ситуацій і підрозділів пожежної охорони як їх складової. Зокрема, постановці та шляхам розв’язання цих проблем були присвячені наукові праці М. Ануфрієва [2], О.Бандурки, [3], В.А. Лаптій [4], В.А Лаптій [5], В. Доманського [6], С. Засунька [7], І. Куца [8], Л.Баличева [9], А.Седляр [10], А. Томіленка [11], О. Труша [12] та інших учених-юристів та практиків. Однак, деякі проблеми залишилися не вирішеними.

Метою написання цієї статті є часткове усунення прогалин у дослідженні цієї проблематики на підставі аналізу розвитку процесу адміністративноправового регулювання організації та діяльності органів 3 надзвичайних ситуацій України, однією з функцій яких є забезпечення пожежної безпеки, а також досвіду країн Свропейського Союзу у попередженні надзвичайних ситуацій та ліквідації їх наслідків.

Процес оновлення законодавства, що закріплює систему та функції органів захисту населення в умовах надзвичайних ситуацій, розпочався вже зі становленням незалежної Української держави, коли була створена Єдина державна система цивільного захисту, яка поєднувала і поєднує зараз функції цивільної охорони та запобігання i реагування на надзвичайні ситуації техногенного та природного характеру. Це було зумовлено прийняттям низки адміністративно-правових актів, спрямованих на підвищення ефективності діяльності органів, покликаних попереджувати надзвичайні ситуації та своєчасно на них реагувати, використовуючи для цього увесь арсенал сил та засобів. 
До здобуття нашою державою незалежності в 1991 році питаннями цивільного захисту та оборони, попередження надзвичайних ситуацій, захисту населення від наслідків Чорнобильської катастрофи, гасіння пожеж та пожежної безпеки займалися три окремих відомства: Штаб цивільної оборони, Міністерство у справах захисту населення від наслідків аварії на ЧАЕС та Головне управління пожежної охорони МВС України.

28 жовтня 1996 року Указом Президента України «Про Міністерство України $з$ питань надзвичайних ситуацій та у справах захисту населення від наслідків Чорнобильської катастрофи» [13] на базі Штабу цивільної оборони та Міністерства у справах захисту населення від наслідків аварії на ЧАЕС було створено центральний орган виконавчої влади - Міністерство України з питань надзвичайних ситуацій та у справах захисту населення від наслідків Чорнобильської катастрофи (МНС України), яке стало провідним органом у системі центральних органів виконавчої влади із забезпечення реалізації державної політики у сфері цивільної оборони, рятувальної справи, поводження $з$ радіоактивними відходами, захисту від надзвичайних ситуацій, попередження таких ситуацій i реагування на них, ліквідації їх наслідків та наслідків Чорнобильської катастрофи. Це міністерство здійснювало керівництво дорученою йому сферою управління та було відповідальним за їі стан і розвиток.

27 січня 2003 року Президентом України був виданий Указ «Про заходи щодо вдосконалення державного управління у сфері пожежної безпеки, захисту населення і територій від наслідків надзвичайних ситуацій» [14], відповідно до якого підрозділи Державної пожежної охорони були виведені зі складу МВС України і стали складовою МНС України.

19 грудня 2003 року було також видано Указ Президента України «Про Державну програму перетворення військ Цивільної оборони України, органів і підрозділів державної пожежної охорони в оперативно-рятувальну службу цивільного захисту на період до 2005 року» [15]. Ця програма передбачала створення єдиної невійськової оперативно-рятувальної служби, тобто було здійснено повну демілітаризацію МНС України.

24 червня 2004 року парламент прийняв Закон України «Про правові засади цивільного захисту» [16], що визначив: правові та організаційні засади у сфері цивільного захисту населення і територій у разі виникнення надзвичайних ситуацій; повноваження відповідних органів виконавчої влади 3 їх попередження та ліквідації наслідків; порядок створення та застосування сил цивільного захисту, їх комплектування, проходження в них служби, а також гарантії соціального та правового захисту особового складу органів і підрозділів цивільного захисту. У 2006 році війська цивільної оборони України були повністю розформовані, а їх особовий склад, а також особовий склад Державної пожежної охорони влився до єдиної Оперативно-рятувальної служби цивільного захисту МНС України. У 2008 році в підрозділах цього міністерства була запроваджена контрактна служба, проведена переатестація особового складу, введені спеціальні звання служби цивільного захисту. 
У відповідності до Указу Президента України від 9 грудня 2010 року «Про оптимізацію системи центральних органів виконавчої влади» [17], Міністерство України з питань надзвичайних ситуацій та у справах захисту населення від наслідків Чорнобильської катастрофи було реорганізовано в Державну службу України 3 надзвичайних ситуацій, одним із напрямків діяльності якої було забезпечення пожежної безпеки. Цим же Указом створені як центральні органи виконавчої влади Державна служба гірничого нагляду та промислової безпеки України та Державне агентство України з управління зоною відчуження.

Із 2011 року розпочалося розділення Міністерства у справах надзвичайних ситуацій України на чотири окремі центральні органи виконавчої влади - Міністерство надзвичайних ситуацій України (як провідний серед них), Державну інспекцію техногенної безпеки України, Державне агентство України з управління зоною відчуження і Державну службу гірничого нагляду та промислової безпеки України.

Згодом, 24 грудня 2012 року, Указом Президента України «Про деякі заходи 3 оптимізації системи центральних органів виконавчої влади» [18] Міністерство надзвичайних ситуацій України і Державна інспекція техногенної безпеки України були реорганізовані в єдину Державну службу України 3 надзвичайних ситуацій як центральний орган виконавчої влади, діяльність якого координувалася і направлялася Кабінетом Міністрів України через Міністра оборони України. Згідно з Положенням про цю службу [19] до ліквідації наслідків надзвичайних ситуацій залучалися підрозділи Збройних Сил України.

Важливою віхою у підвищенні ефективності правового регулювання вказаних вище органів стало прийняття Кодексу цивільного захисту України, [20], який набув чинності 1 липня 2013 року.

Постановою Кабінету Міністрів України від 25 квітня 2014 року № 120 «Питання спрямування та координації діяльності Державної служби України 3 надзвичайних ситуацій» [21] прийняте рішення про те, що діяльність служби спрямовується та координується Кабінетом Міністрів України через Міністра внутрішніх справ України, що в подальшому знайшло відображення і в постанові КМУ України від 10 вересня 2014 року «Про оптимізацію системи центральних органів виконавчої влади» [22]. Це сприяло досягненню узгодженості та координації сил Міністерства внутрішніх справ України та Міністерства оборони України при здійсненні ними спільних дій в умовах зовнішньої агресії, а також при ліквідації наслідків надзвичайних ситуацій в державі.

Прийняття цього рішення було зумовлене низкою недоліків у структурній побудові та практичній діяльності цієї служби. Негативно відбивалося на ефективності ii роботи також недофінансування, недостатня кількість службовців, які безпосередньо беруть участь у тушінні пожеж та ліквідації наслідків інших надзвичайних ситуацій, та їх перевантаження роботою. 
1 квітня 2014 року уряд схвалив Концепцію реформування місцевого самоврядування та територіальної організації влади в Україні [23], запровадження якої має створити, зокрема, належні матеріальні, фінансові та організаційні умови для забезпечення здійснення органами місцевого самоврядуванні власних і делегованих повноважень, у тому числі й із забезпечення пожежної безпеки.

Незважаючи на те, що правовому регулюванню діяльності органів 3 надзвичайних ситуацій приділялася належна увага, воно ще не у достатній мірі сприяє ефективності їх роботи і не враховує позитивний, як видається, досвід країн Свропейського Союзу щодо організації діяльності відповідних їх служб.

Так, наприклад, у Португалії створене Національне управління з питань цивільного захисту, яке відповідає за запобігання надзвичайним та кризовим ситуаціям. Підпорядковується воно міністерству внутрішніх справ. Основними його функціями є планування, координація та здійснення державної політики, зокрема, у сфері запобігання надзвичайним ситуаціям та катастрофам, реагування на них, надання захисту та допомоги населенню, а також нагляд за діяльністю пожежних і рятувальних служб. У сфері планування своїх дій це управління розробляе основні напрямки діяльності у надзвичайних ситуаціях; координує діяльність державних та недержавних служб у сфері транспорту, енергетики, сільського господарства, рибальства та продовольства, промисловості і зв'язку з метою забезпечення захисту населення та майна у випадках пожеж, інших надзвичайних ситуацій та катастроф. Структурно Національне управління 3 питань цивільного захисту складається 3 трьох національних директоратів, а саме: 3 планування дій у випадках надзвичайних ситуацій ( до якого входять управління з планування та прогнозування ризиків і запобігання їм), пожежних та рятувальних служб, а також ресурсів цивільного захисту.

У республіці Румунії Міністерство внутрішніх справ та адміністративної реформи є центральним органом виконавчої влади, яке відповідає за питання запобігання надзвичайним та кризовим ситуаціям, здійснює реагування на ці ситуації. Його діяльність спрямовується і координується урядом Румунії. До складу цього міністерства входить Генеральний інспекторат з надзвичайних ситуацій. До його основних завдань належать: проведення спеціальних планових заходів 3 метою запобігання надзвичайних ситуацій; зменшення або виключення ризиків виникнення надзвичайних ситуацій; реагування на надзвичайні ситуації та ліквідація їх наслідків; здійснення державного пожежного контролю; забезпечення координації дій органів виконавчої влади, органів місцевого самоврядування, цивільних, добровільних та приватних підрозділів.

У республіці Кіпр головним державним органом у системі цивільної оборони є Рада міністрів, очолювана президентом країни, а відповідальною особою за виконання положень кіпрського законодавства в зазначеній сфері від імені Ради Міністрів $є$ міністр внутрішніх справ країни, який також наділений контрольними та наглядовими функціями. Основною метою діяльності 
підрозділів цивільної оборони є запровадження відповідних заходів, спрямованих на захист населення Кіпру, надання йому швидкої допомоги від наслідків різного виду катастроф та забезпечення передумов для його виживання в надзвичайних ситуаціях. Структурно підрозділи цивільної оборони складаються 3 таких секцій: секція з надання першої допомоги; телекомунікаційна секція; секція соціального забезпечення; секція боротьби з пожежами; секція 3 питань пошуку та спасіння [24].

Отже, з проведеного аналізу можна зробити висновок, що в країнах Європи система цивільного захисту суттєво відрізняється від існуючої в Україні $\mathrm{i}$, як свідчить практика iï функціонування, вона забезпечує ефективний захист населення у разі виникнення на територіях своїх держав пожеж та інших надзвичайних ситуацій. Слід зазначити, що частково європейський досвід функціонування органів цивільного захисту врахований вже в нашій державі. Зокрема, у затвердженому Урядом Положенні про Міністерство внутрішніх справ України від 28.10.2015 року № 878 [25] визначено, що окрім Національної поліції, Національної гвардії, Державної міграційної служби, Державної прикордонної служби, до його складу входить і Державна служба України з надзвичайних ситуацій, яка $\epsilon$ відповідальною за реалізацію відповідних заходів у сфері цивільного захисту населення та пожежно-рятувальної справи.

У цьому ж році, з урахуванням європейських норм і стандартів, були внесені зміни до деяких адміністративно-правових актів, зокрема, щодо скорочення кількості підрозділів Державної служби з надзвичайних ситуацій. Була запроваджена також європейська модель підбору, розстановки, навчання та підвищення рівня фахової підготовки іiі кадрів.

25 січня 2017 року Кабінет Міністрів України затвердив Стратегію реформування системи Державної служби з надзвичайних ситуацій [26] , яка буде здійснюватися у три етапи протягом 2017-2020 років. Основним її завданням $є$ підвищення спроможності цієї служби щодо протидії загрозам національній безпеці у сфері цивільного захисту. За результатами запровадження Стратегії очікується забезпечення належного рівня безпеки життєдіяльності населення, захист суб'єктів господарювання і територій від загрози виникнення надзвичайних ситуацій; створення ефективної сучасної європейської системи запобігання виникненню пожеж та інших надзвичайних ситуацій; удосконалення системи реагування на пожежі та інші небезпечні події; скорочення часу прибуття пожежно-рятувальних підрозділів до місця виклику (до 10 хвилин у місті та до 20 хвилин у сільській місцевості); зменшення збитків національної економіки та населення у разі виникнення пожеж, інших надзвичайних ситуацій, небезпечних гідрометеорологічних явищ; створення оптимальної системи управління єдиною державною системою цивільного захисту та підвищення ефективності їі функціонування.

Утім, вже сьогодні діяльність Державної служби України з надзвичайних ситуацій потребує подальших кардинальних організаційних змін, розробки чітко визначених перспективних планів роботи, детального розподілу 
професійних повноважень іiї службовців. Для цього необхідно, як це запроваджено в країнах Європейського Союзу, створити єдину систему цивільного захисту з чітким визначенням функцій структурних елементів цієї системи і здійснити комплектування складу службовців - справжніх професіоналів, на конкурсній основі. Тобто, сьогоднішня Державна служба України з надзвичайних ситуацій має стати професійним, високоефективним інститутом європейського зразка, основаним на єдиному механізмі рятувальної служби як провідного органу щодо захисту населення від пожеж та інших подій техногенного та природного характеру.

Що ж до подальшого правового регулювання ï практичної діяльності, то його напрямки мають бути визначені в ході проведення відповідних досліджень представниками адміністративно-правової науки та практичними працівниками цієї Служби.

Отже, можна зробити наступні висновки. Наша держава в особі Президента України, парламенту, уряду, центральних органів виконавчої влади 3 часів проголошення незалежності України і до сьогодні приділяли i приділяють значну увагу питанням цивільного захисту населення і всієї країни від наслідків пожеж та інших надзвичайних ситуацій техногенного та природного характеру, попередження цих ситуацій, ліквідації їх наслідків, про що свідчить створення та вдосконалення системи відповідних державних органів і адміністративно-правове регулювання їх діяльності. Втім, недостатньо ще враховується досвід країн СС щодо попередження надзвичайних ситуацій та ліквідації їх негативних наслідків. А це зумовлює необхідність проведення представниками науки адміністративного права подальших досліджень щодо визначення можливості та необхідності імплементації відповідних норм законодавства Європейського Союзу в законодавство України з метою підвищення ефективності діяльності органів реагування на надзвичайні ситуації та їх попередження.

\section{Лiтература}

1. Конституція України : Закон України від 28.06.1996 р. № 254к/96-ВР. Відомості Верховної Ради України. 1996. №30. 141 с.; 2. Ануфрієв М.І. Організаційно-правові засади управління безпекою життєдіяльності працівників органів внутрішніх справ України: Науково-практичний посібник. Ун-т внутр. справ, Харків, 1998. 32 с; 3. Бандурка О.М. Основи діяльності міліції в надзвичайних ситуаціях. Пожежна безпека: Матеріали Всеукраїнської науково-технічної конференції. Київ, 1993. 11-13 с.; 4. Лаптій В.А. Управління державними органами в особливих умовах: Проблеми удосконалення. УАВС. Науковий вісник. Київ,1996. Вип. 2,155-159 с; 5. Лаптій В.А. Організація роботи державних органів у надзвичайних ситуаціях. Проблеми реформування державної влади: Конституційні та управлінські аспекти: Тези доповіді і наукове повідомлення науково-практичної конферениії. Київ, 10-11 березня 1995. 155-156 с; 6. Доманський В.А. Державне управління пожежною безпекою України (організаційно-правовий аналіз за матеріалами діяльності Державного департаменту пожежної безпеки): дис. ...канд. юрид. наук: 12.00.07. Харків, 2004. 201 с; 
7. Засунько С.С. Адміністративна відповідальність за правопорушення у сфері пожежної безпеки : Держава і право. Збірник наукових пращъ. - Київ, 2004. Випуск 24. 234 - 241 с.; 8. Куц І.Г. Боротьба з пожежами в житловому секторі (кримінально-правовий та кримінологічний аспекти): дис. ... канд. юрид. наук: 12.00.08. Київ, 2003. 209 с; 9. Баличева Л. Створення, організація та діяльність системи пожежної безпеки в Україні (XIX - початок XX ст.): дис. ...канд. іст. наук: 07.00.01. Харків. 2005. 193 с; 10.Седляр А. Заходи органів міського громадського управління Волині та Поділля у сфері пожежної охорони наприкінці XIX - на початку ХХст. Київ, 2007. 44-49 с. 11. Томіленко А. Пожежна справа на Правобережній Україні в другій половині XIX - на початку XX ст.: дис. ... канд. іст. наук: 07.00.01. Черкаси, 2000. 207 с; 12. Труш О.О. Досвід побудови та функціонування систем цивільного захисту країн-членів Європейського Союзу: зб. наук.пр. Київ, 2010, вип.1(28) 407-417 с.; 13. Про Міністерство України з питань надзвичайних ситуацій та у справах захисту населення від наслідків Чорнобильської катастрофи : Указ Президента України від 28.10.1996 р. № 1005/96. URL: https://zakon.rada.gov.ua/laws/show/1364-96-\%D0\%BF (дата звернення 12.03.2019); 14. Про заходи щодо вдосконалення державного управління у сфері пожежної безпеки, захисту населення і територій від наслідків надзвичайних ситуацій (органи i підрозділи Державної пожежної охорони виведені зі складу МВС і передані до складу МНС України): Указ Президента України: від 27.01.2003p. №47/2003 URL: https://zakon.rada.gov.ua/laws/show/47/2003 (дата звернення 15.05.2019); 15. Про Державну програму перетворення військ Цивільної оборони України, органів і підрозділів державної пожежної охорони в оперативно-рятувальну службу цивільного захисту на період до 2005 року: Указ Президента України від 19.12.2003p.№1467/2003 URL: https://zakon.rada.gov.ua/ laws/show/1467/2003 (дата звернення 15.05.2019); 16. Про правові засади цивільного захисту : Закон Украӥни від 24.09.2008p.№ 588-VI URL: https://zakon.rada.gov.ua/laws/show/1859-15 (дата звернення 15.05.2019). 17. Про оптимізацію системи центральних органів виконавчої влади : Указ Президента України від 9.12.2010 p. № 1085/2010 URL: https://zakon2.rada. gov.ua/laws/show/1085/2010 ( дата звернення 15.05.2019); 18. Про деякі заходи з оптимізації системи центральних органів виконавчої влади: Указ Президента України від 24.12.2012 р. № 1085/2010 URL: https://zakon.rada.gov.ua/laws/show/726/2012 (дата звернення 15.05.2019); 19. Деякі питання Державної служби України з надзвичайних ситуацій: Указ Президента України від 16.01.2013.p.№20/2013 URL:https://zakon.rada.gov.ua/laws/show/20/2013 (дата звернення 15.05.2019); 20. Кодекс цивільного захисту України: Відомості Верховної Ради України. офіційне видання від 02.10.2012. 2012 р. № 5403/VI URL: https://zakon.rada.gov.ua/ laws/show/5403-17 (дата звернення 15.05.2019); 21. Питання спрямування та координації діяльності Державної служби з надзвичайних ситуацій : Постанова КМУ від 25 квітня 2014 р. №120 URL: https://zakon.rada.gov.ua/laws/show/120-2014-\%D0\%BF (дата звернення: 15.05.2019); 22. Про оптимізацію системи центральних органів виконавчої влади : Указ Президента України від 10.09.2014 №442 URL: https://zakon.rada.gov.ua/laws/show/1085/2010 (дата звернення: 15.05.2019); 23. Концепція реформи місцевого самоврядування та територіальної організації влади в Україні. від 01.04.2014 p. №333-p URL: zakon.rada.gov. ua/ laws/show/333-2014-p (дата звернення: 15.05.2019); 24. Труш О.О. Досвід побудови та функціонування систем цивільного захисту країн-членів Свропейського Союзу: зб.наук.пр., Київ, 2010 вип.1(28) ; 25.Положення про Міністерство внутрішніх справ Украӥни. від 28.10.2015p.№878 URL:https://zakon.rada.gov.ua/laws/show/878-2015-\%D0\%BF\#n10 (дата звернення: 15.05.2019); 26. Про схвалення Стратегії реформування системи Державної служби України 3 надзвичайних ситуацій від 25.01.2017p. №64-p. URL: https://zakon.rada.gov.ua/ laws/show/61-2017-\%D1\%80 (дата звернення: 15. 05. 2019). 